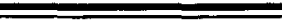 EPSL
}

ELSEVIER

Earth and Planetary Science Letters $123(1994)$ 1-13

\section{The Neoproterozoic (1000-540 Ma) glacial intervals: No more snowball earth?}

\author{
Joseph G. Meert, Rob van der Voo \\ University of Michigan, Department of Geological Sciences, 1006 C.C. Little Building, Ann Arbor, MI 48109, USA
}

(Received July 26, 1993; revision accepted March 17, 1994)

\begin{abstract}
The Neoproterozoic interval (1000-540 Ma) contains ample evidence for a series of glacial intervals. These include the 750-700 Ma Sturtian glaciation, the 625-580 Ma Marinoan-Vendian glaciation and the 600-550 Ma Sinian glaciation. Paleomagnetic evidence has suggested that many of these glaciations occurred at tropical latitudes $\left(\leqslant 25^{\circ}\right)$ and this led to a number of theories that attempt to explain the occurrence of these anomalously low latitude glaciations (e.g., an increase in the axial tilt of the earth, an equatorial low-orbit ice-ring, rapid equator to pole continental drift, incorrect identification of impact deposits as glacial deposits or secondary magnetizations misidentified as primary). New paleomagnetic data for Laurentia, China, Baltica and parts of Gondwana are combined with a reanalysis of previously published data to demonstrate that the Neoproterozoic glaciations may well all have occurred above $25^{\circ}$ latitude. Climate models using a juvenile Sun of slightly lower luminosity, lower $\mathrm{CO}_{2}$ levels and coupling to Milankovitch cycles suggest that ice sheets could extend to within $\pm 25^{\circ}$ of the Neoproterozoic equator. Thus, the new paleomagnetic data and climate models offer an alternative explanation for the Neoproterozoic glaciations that is consistent with the waxing and waning of intermediate latitude ice sheets to form the conformable sequences of warm climate-cold climate strata.
\end{abstract}

\section{Introduction}

One of the most puzzling features of the Neoproterozoic (1000-540 Ma) is the apparent prevalence of low-elevation continental glaciations that occurred at tropical latitudes $\left(\leqslant 25^{\circ}\right)$. The prima facie evidence for these low-latitude glaciations was provided by paleomagnetic studies of the Elatina Formation in the Adelaide geosyncline of Australia [1,2]. Further paleomagnetic support for low-latitude Neoproterozoic glaciations were

$\overline{\text { [MK] }}$ provided for South Africa [3], south China [4], the Tarim block [5] and Laurentia [6]. A number of contrasting theories have been proposed to explain these enigmatic episodes of global refrigeration:

(a) A significant increase in the earth's obliquity to $\geqslant 54^{\circ}[7]$.

(b) Incorrect identification of glaciogenic deposits $[8,9]$.

(c) Glaciations that extended over all latitudes during severe ice ages (also known as the 'snowball earth' [10]).

(d) A Saturn-like equatorial ice ring that shielded the low latitudes from the Sun [11]. 
(e) A significant departure from the geocentric axial dipole model during the interval 1000 $540 \mathrm{Ma}$ [2].

(f) That glaciogenic rocks were accumulated at intermediate and high latitudes but acquired their remanence at low latitudes after a period of rapid drift to the equator [12].

(g) Conceptual models that indicated lower mean global temperatures for a ringworld supercontinent (e.g., centered and distributed longitudinally about the equator) [13].

(h) Cooler global temperatures because of the lower luminosity $(5-10 \%)$ of the juvenile Sun [14].

All of the above explanations for the low-latitude glaciations were developed wholly or partly to satisfy the available paleomagnetic data. New paleomagnetic data from Laurentia $[15,16]$, South China [17], East Gondwana [18] and Baltica [19], when combined with a re-evaluation of the older paleomagnetic data, suggest that many of these glaciations took place at latitudes $\geqslant 25^{\circ}$. Recently developed climate models link the $\mathrm{Mi}$ lankovitch-cycle parameters, a slightly lower $(6 \%)$ luminosity for a younger Sun and present-day $\mathrm{CO}_{2}$ levels to explain the possibility of ice sheets extending to within $25^{\circ}$ of the equator for a supercontinent distributed through a range of latitudes [14]. This model cannot account for ice sheets extending below $25^{\circ}$ and the critical question thus becomes 'how low is low latitude'.

\section{Obliquity changes and other explanations for low-latitude glaciations}

The last major interval of glaciation took place during the Pleistocene epoch and the extent of the ice sheets on Laurentia reached a latitude minimum of $40^{\circ} \mathrm{N}$ [20]. A similar latitudinal extent for the Pleistocene glaciation was indicated in Siberia and Europe [21]. Likewise, the extent of the Carboniferous glaciations in Gondwana [22] are confined to intermediate to high latitudes $\left(45^{\circ}-90^{\circ}\right)$. The Neoproterozoic glaciations appeared enigmatic as most of the previously published paleomagnetic data indicated that these glaciations occurred at latitudes less than $25^{\circ}$.
These observations led to a number of suggestions ( $\mathrm{a}-\mathrm{h}$ above) to explain the prevalence of tropical ice sheets. These theories tend to 'explain' one or more features of the Neoproterozoic glaciations but cannot account for all of the observations. Williams [7] summarized the evidence for a drastic change in the obliquity of the earth during the Neoproterozoic and earlier times. The change in obliquity to $\geqslant 54^{\circ}$ would, according to the model, result in the reversal of climatic zonations and zonal surface winds. Thus, low latitudes would be preferentially glaciated over high latitudes. There are at least two problems with such an interpretation. An increase in the axial tilt of the earth is a feature to be expected in the distant future rather than the distant past [23] and it fails to explain the occurrence of both glacial and evaporite deposits over a wide range of paleolatitudes [24]. In addition, independent evidence [25] from stromatolite growth models shows that the obliquity of the earth at $850 \mathrm{Ma}$ was essentially the same as that of the present-day earth $\left(\approx 23.5^{\circ}\right.$.

Although it is possible that some of the glacial deposits were incorrectly identified [9] or can be attributed to extraterrestrial impacts [8] it is unlikely that all of these deposits were incorrectly identified. Similarly, the suggestion [10] that the entire globe was covered by an ice sheet (snowball earth) fails to explain the diachronous glaciations $[2,26]$.

A Saturn-like equatorial ice ring surrounding the Neoproterozoic earth [11] is unlikely to have survived the intense solar radiation, even for a juvenile Sun of lower luminosity [7]. In addition, Saturn has an obliquity $\left(26.7^{\circ}\right)$ that is similar to that of the present-day Earth and yet there is no effect on its mean annual daily insolation atrributable to its equatorial rings [27].

Finally, a climate model has been developed [13] that showed a first-order coupling of paleogeography (landmass distribution) and $\mathrm{CO}_{2}$ with global mean surface temperature and latitudinal contrast. This model produced counterintuitive results in that a fully emergent ringworld (supercontinent on the equator) would have an average global temperature lower than that of a halfemergent capworld (supercontinent at the pole). 
However, this model predicted ice-cap formation at intermediate $\left( \pm 45^{\circ}\right)$ latitudes but could not explain ice sheets at the equator.

What is clear from the available data for the interval $1000-540 \mathrm{Ma}$ is that there is abundant evidence for continental glaciations [28] (Fig. 1 shows the distribution of the glacial deposits discussed in this paper). Harland [28] listed peaks of continental glaciations at ca. $950 \mathrm{Ma}$ (Lower Congo, Africa), 750-700 Ma (Sturtian), 625-580 $\mathrm{Ma}$ (Ice Brook-Marinoan-Vendian-Varangian) and 600-550 Ma (Sinian, China). The age estimates indicated have changed somewhat due to better isotopic dating techniques but separate glacial intervals are still recognized.

The synchroneity of glaciations from continent to continent during these glacial epochs is based largely on the inference that each interval represents a global glaciation [10]. Critical evidence for globally synchronous glaciations is lacking (e.g., age data on the glacial deposits) but has been inferred by proxy records of faunal diversity [29] and $\mathrm{CO}_{2}$ levels [30] and sea level [10]. Crowley and Baum [14] attempted to explain the possible climatological requirements for low-latitude glaciations. Their climate models showed a sensitivity of ice-sheet formation to landmass distribution, $\mathrm{CO}_{2}$ levels, Milankovitch orbital forcing and a less luminous Sun. The net potential effect of their models is to allow for low-elevation ice sheets to exist within $\pm 25^{\circ}$ of the equator. Global glaciations were not ruled out by their models but required drastic changes in $\mathrm{CO}_{2}$ levels. They also noted that a fully glaciated Earth may simply have been an artifact of a snowline instability in the climate model.

Eyles [9] noted that the Neoproterozoic glaciations were neither synchronous nor low elevation. According to his analysis, glacial deposits in the Neoproterozoic are intimately associated with active tectonic settings. The glaciations are confined to the uplifted regions formed during extension or compression.

\section{Geomagnetic and paleomagnetic explanations}

Other possible explanations for the apparent low-latitude glaciations are directly related to ge- omagnetism and paleomagnetism. The most commonly cited explanation for the observations is that the geocentric axial dipole model for the earth's field is not valid during the interval 1000 $540 \mathrm{Ma}$ or, coincidentally, the glaciogenic intervals. Such an explanation can account for the apparent low-latitude glaciations but does not support the bulk of the paleomagnetic evidence for this time interval $[1,7,31]$. The suggestion [12] that glaciogenic rocks accumulate at intermediate to high latitudes and acquire their remanence at low latitudes following rapid drift from pole to equator is apparently at odds with the paleomagnetic data from the Elatina Formation [2]. However, Piper [31] noted that his supercontinental reconstruction and its apparent polar path (APWP) during the interval $1000-540 \mathrm{Ma}$ was entirely compatible with the drift of continents into and out of glaciated intermediate to high latitudes. Both the interpretation of [12] and [31] require diachronous Neoproterozoic glacial intervals at odds with the snowball earth. The paleomagnetic explanations for tropical glaciations include incomplete averaging of secular variation, the acquisition of remanence during an excursion or reversal of the earth's magnetic field, and secondary magnetizations identified as primary. These explanations are explored below for each of the major continents.

\subsection{Africa: Lower Congo glacial epochs (950 and $750 \mathrm{Ma}$ )}

The representative lithologies for the Lower Congo glacial epoch are the Petit and Grand Conglomérat of Shaba, Zaire and Zambia (squf, Fig. 1). These rocks have not been directly dated but are thought to be correlative with the lower part of the Bukoban succession in Tanzania [32,33]. The age of the Grand Conglomérat is roughly $950 \mathrm{Ma}$ and the age of the Petit Conglomérat is roughly $750 \mathrm{Ma}$. Neither of these rock units have been studied paleomagnetically, and their presumed latitude is based on the paleomagnetic results from the Bukoban rocks [34]. The mean paleomagnetic pole for the Bukoban succession is $29^{\circ} \mathrm{S}, 283^{\circ} \mathrm{E}\left(A_{95}=11^{\circ}\right)$, corresponding to depositional paleolatitudes of $5^{\circ} \pm 12^{\circ}$ for 
these glaciations. However, the best age estimate for the Bukoban is $805 \mathrm{Ma}$, and so the correlation of the Bukoban pole to the glacial units of the Petit and Grand Conglomérat is questionable. Furthermore, both of these units have been interpreted as fluvioglacial deposits sourcing alpinetype glaciers from the Kibaran mountains to the east [33]. Therefore, there is adequate evidence for a glaciation on the Congo craton but these deposits may not have been low elevation and their paleolatitude remains unknown.

\subsection{Africa: South Africa and Namibia}

Continental glacial and fluvioglacial deposits from southern Africa and Namibia include formations within the Damara Supergroup, the Gariep Group and the Nama Group (- $\bullet$, Figs. 1 and 2). The original age estimates for these deposits are provided in [35] and [36]. These ages are between $800-850 \mathrm{Ma}$ for the Blaubeker diamictite (Damara Supergroup), $740 \mathrm{Ma}$ for the Chuos Formation diamictite (Damara Supergroup), 600-780 Ma for the Numees diamictite
(Gariep Group), and 600-620 Ma for the Schwarzrand diamictites of the Nama Group. Many of these same rocks have been studied paleomagnetically $[3,36]$. The assignment of magnetization ages to the various components was indirect and, as noted by Van der Voo and Meert [37], the position of the Kalahari craton during the interval 900-600 $\mathrm{Ma}$ is essentially unconstrained by reliable paleomagnetic studies. Recent geochronologic and paleontologic data [38] indicate that the paleomagnetic results of [3] and [36] may all be the result of early Paleozoic remagnetizations. These new chronometric data also suggest a significant downward calibration in the age of the Nama Group to $550 \mathrm{Ma}$. A new age progression for the paleomagnetic poles for southern Africa and Namibia is shown in Fig. 2 (a complete listing of paleomagnetic poles can be found in Van der Voo and Meert [37]) and is compatible with the paleomagnetic and chronologic data but not entirely satisfying because of the difficulty in assigning ages to the various magnetic components. The likelihood that all the Nosib, Nama and Blaubeker poles are the result

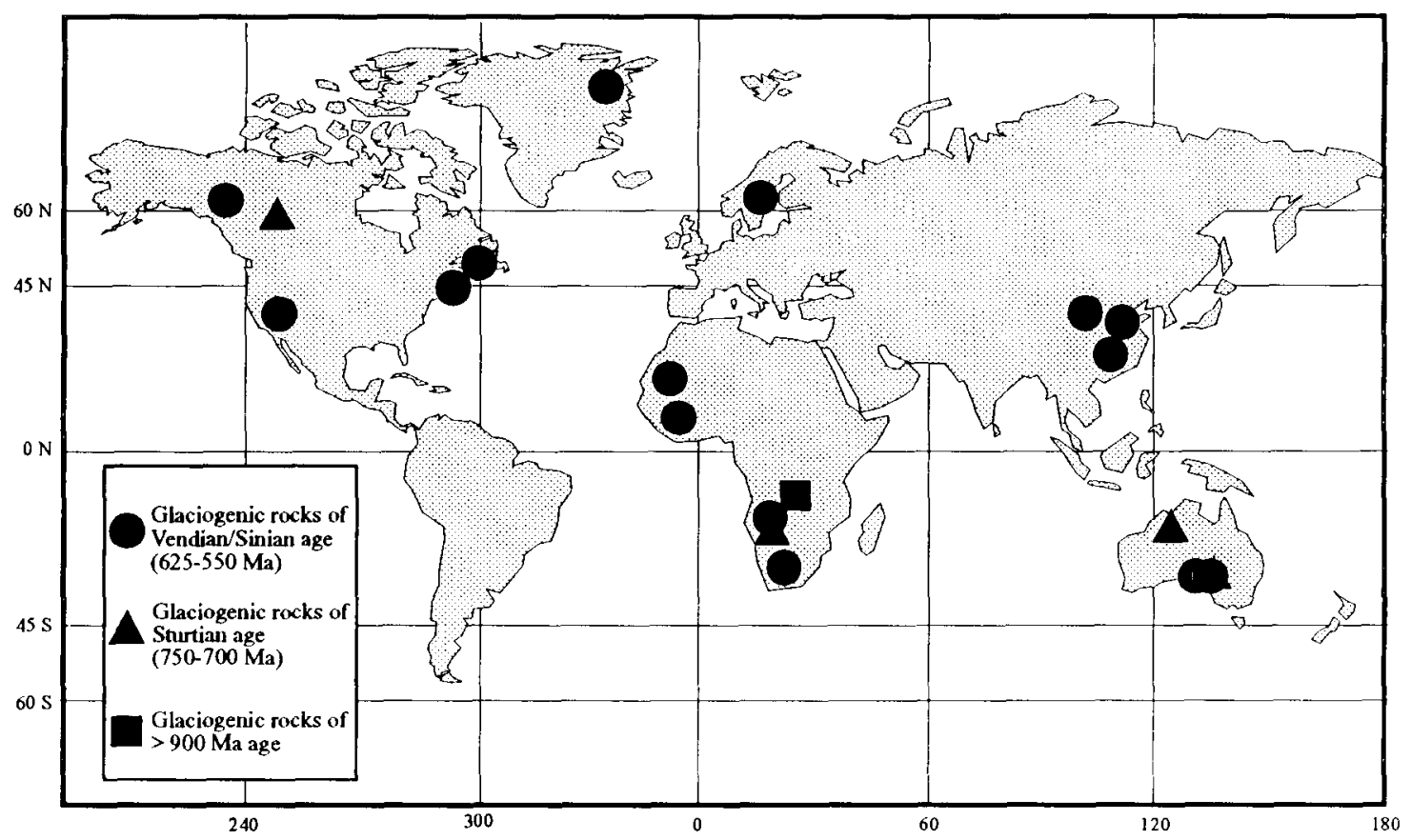

Fig. 1. Map showing locations of selected glaciogenic rocks formed during the interval 1000-540 Ma. 


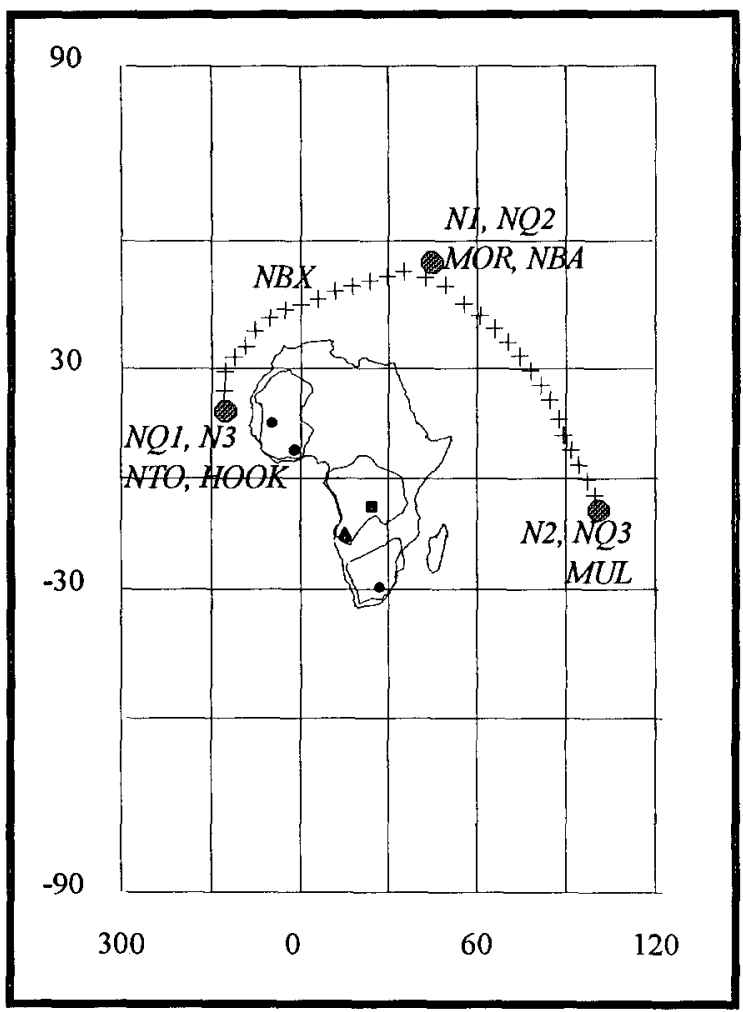

Fig. 2. Late Proterozoic-Early Cambrian apparent polar wander path for the Kalahari-Congo Cratons. $N 1, N 2$ and $N 3=$ Nama Group poles [3]; $N Q 1, N Q 2$ and $N Q 3=$ Nosib Group poles [36]; $N B A$ and $N B X=$ Blaubeker diamictite poles [3]; $M O R=$ Adoud andesite Morrocan pole [37]; $N T O=$ Ntonya Ring structure pole [37]; $H O O K=$ Hook intrusives pole [37].

of latest Precambrian-early Paleozoic remagnetizations associated with tectonic events in these regions suggests the following sequence of magnetic ages: The oldest pole in the sequence is now believed to be the N2 (Nama) pole that is coincident with the NQ3 (Nosib) pole and the pole for the Mulden Group (Fig. 2). These three poles give a $550 \mathrm{Ma}($ ?) mean paleomagnetic pole at $10^{\circ} \mathrm{S}, 098^{\circ} \mathrm{E}\left(A_{95}=20^{\circ}\right)$. The calculated paleolatitude of $12^{\circ} \pm 20^{\circ}$ is rendered meaningless in terms of determining the latitude of the glacial sediments during deposition because the remagnetization is unlikely to have been primary or the result of early diagenesis. In any case, paleolatitude of $\geqslant 25^{\circ}$ is within the errors of paleomag. netic detection. The next younger sequence of poles comprises the Nama I pole $(\mathrm{N} 1)=$ Nosib II pole $(\mathrm{NQ2})=$ Morroco pole $(\mathrm{MOR})=$ Blaubeker A pole (NBA), with an age of $530 \mathrm{Ma}$. The mean location of this group of remagnetized poles is $56^{\circ} \mathrm{N}, 44^{\circ} \mathrm{E}\left(A_{95}=12^{\circ}\right)$. The youngest sequence is represented by the Ntonya Ring structure pole (NTO), the Nosib I pole (NQ1), the Hook Intrusives pole (HOOK) and the Nama III pole (N3), with an age of $520 \mathrm{Ma}$. Powell et al. [18] posited a Cambrian age for the final amalgamation of Gondwana and it may be that this event is responsible for the Cambrian remagnetization of these poles.

The Blaubeker diamictite of the Damara Supergroup unconformably underlies the Nama Group and unconformably overlies the Nosib Group of the Damara Supergroup [3] and the concordance of its paleomagnetic pole with younger poles suggests a later remagnetization. The paleolatitude of the Blaubeker diamictite is unknown. A clear resolution for the paleolatitudes of the southern Africa-Namibia glaciations requires better dated paleomagnetic poles [37].

\subsection{Africa: West Africa}

Accepting the sequence of paleomagnetic poles described above and noting that the best constrained early Paleozoic pole is the Ntonya Ring pole (NTO), the $520-550 \mathrm{Ma}$ glacial tillites is West Africa formed at intermediate to high latitudes. These tillites include the Jbeliát Group in the Taoudeni Basin (Mauritania), the Tabe Formation in Sierra Leone and the Kodjani tillite and equivalents in Benin, Ghana, Niger, Togo and Upper Volta [35].

\subsection{China}

The lower Sinian / Cambrian glacial epoch took place between 600 and $550 \mathrm{Ma}$ and glacial deposits of this sequence are well exposed throughout China, particularly in regions of the South China Block (SCB) and Qinling. Both the Nantuo tillite on the SCB and the Luoquan tillite on the North China Block (NCB) are interpreted as continental glacial or glaciomarine deposits [35]. The inferred paleolatitudinal position for the $\mathrm{NCB}$ between $42^{\circ}$ and $55^{\circ}$ is based on paleomagnetic 
data from the Luoquan and Xinji Formations [35]. Slightly lower paleolatitudes $\left(23^{\circ} \pm 12^{\circ}\right)$ for the Sinian NCB were obtained in a recent study [39]; however, most of the sites used are lower Cambrian in age, or younger, so the calculated paleolatitude of $23^{\circ}$ is somewhat biased by the lower inclination of the younger results. The paleolatitude for NCB calculated from Sinian-age rocks in that study is approximately $30^{\circ}$. Previously published paleomagnetic results from the SCB [4] suggested that the Nantuo tillite was formed at low paleolatitudes $\left(0^{\circ}-25^{\circ}\right)$. A more recent paleomagnetic study of the Gechongwu Sinian section in Guizhou province [17] recognized that the earlier results [4] match the Permo-Triassic poles for the SCB. Wang [17] showed that this Permo-Triassic remagnetization is ubiquitous throughout China and his new Sinian pole for the SCB indicated that it likely occupied intermediate latitudes $\left(40^{\circ} \pm 7^{\circ}\right)$ during the Sinian glaciation. These new data and interpretations for China are consistent with ice-sheet formation at intermediate, rather than low, paleolatitudes for the Sinian continental glaciations. Fig. 3 shows the paleolatitudinal positions of the $\mathrm{NCB}$ and SCB based on these new data.

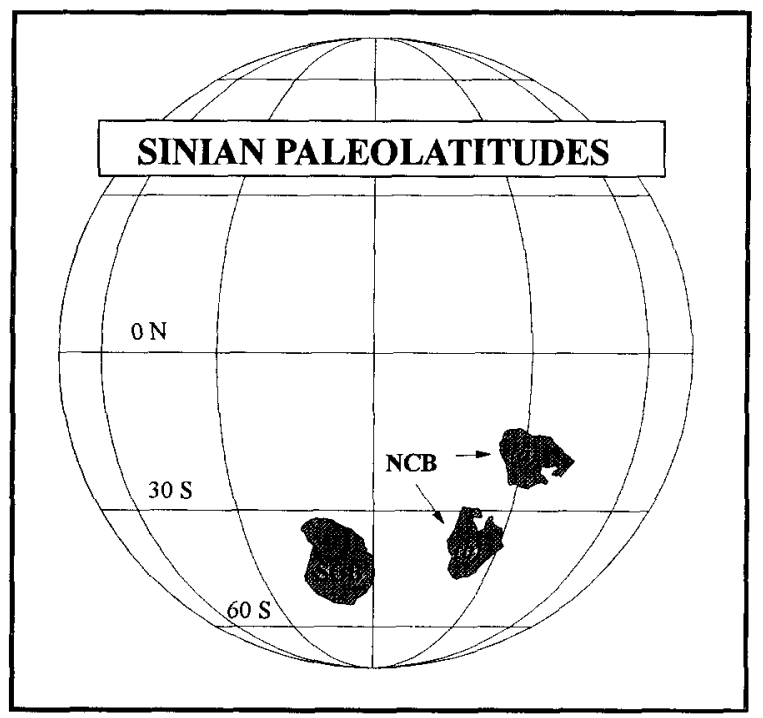

Fig. 3. Sinian paleolatitudinal position for the South China Block (SCB) according to [17], the North China Block NCB(a) according to the data in [35] and the $\mathrm{NCB}(\mathrm{b})$ according to [39].

\subsection{North America and Australia}

The most abundant data that apparently confirmed the existence of low-latitude, low-elevation, continental glaciations are from Laurentia and Australia. There were two main intervals of glaciation on these continents. The first, called the Sturtian (Australia) or Rapitan (Laurentia), was estimated to have occurred between 750 and 700 m.y. ago. A recent hypothesis [40] suggests that a supercontinent was fully formed by this time with the western margin of Laurentia (all directions refer to present-day coordinates) juxtaposed against eastern Australia and the East Antarctic craton (Fig. 4a). There is adequate paleomagnetic evidence for this reconstruction (see [18] for a more complete discussion). Fig. 4b shows the paleomagnetically constrained reconstruction for Laurentia and proto-East Gondwana at $720 \mathrm{Ma}$ according to [18]. The mean 720 Ma pole [18] is based on the paleomagnetic poles from the Malani Rhyolite (India), the Yilgarn Block B-dikes (Australia), and the Franklin diabases and the Natkusiak Formation (Laurentia) and falls at $81^{\circ} \mathrm{S}, 236^{\circ} \mathrm{E}\left(A_{95}=17^{\circ}\right.$, in present-day India coordinates). This paleomagnetic pole translates to paleolatitudes greater than $25^{\circ}$ for both the Rapitan and Sturtian glacial deposits. The evidence used to support the tropical nature of the Sturtian-Rapitan glaciations came from the sedimentary units underlying the glacial deposits because they contain warm-water carbonates. However, the proximity of these continents to both the glacial limit and tropical latitudes suggests that Milankovitch forced climate change can account for the shift in facies over a relatively short time interval.

Breakup of proto-East Gondwana and Laurentia was estimated to have occurred shortly after the Sturtian-Rapitan glaciation [18] as Laurentia drifted toward the pole [15] and proto-East Gondwana remained quasi-static (i.e., little latitudinal change). The Marinoan-Ice Brook (e.g., Vendian) glaciations occurred, according to Powell et al. [18], following this breakup and preceding a second phase of rifting in Laurentia (i.e., between 625 and $580 \mathrm{Ma}$ ). The Ice Brook glaciations on Laurentia were previously considered to 


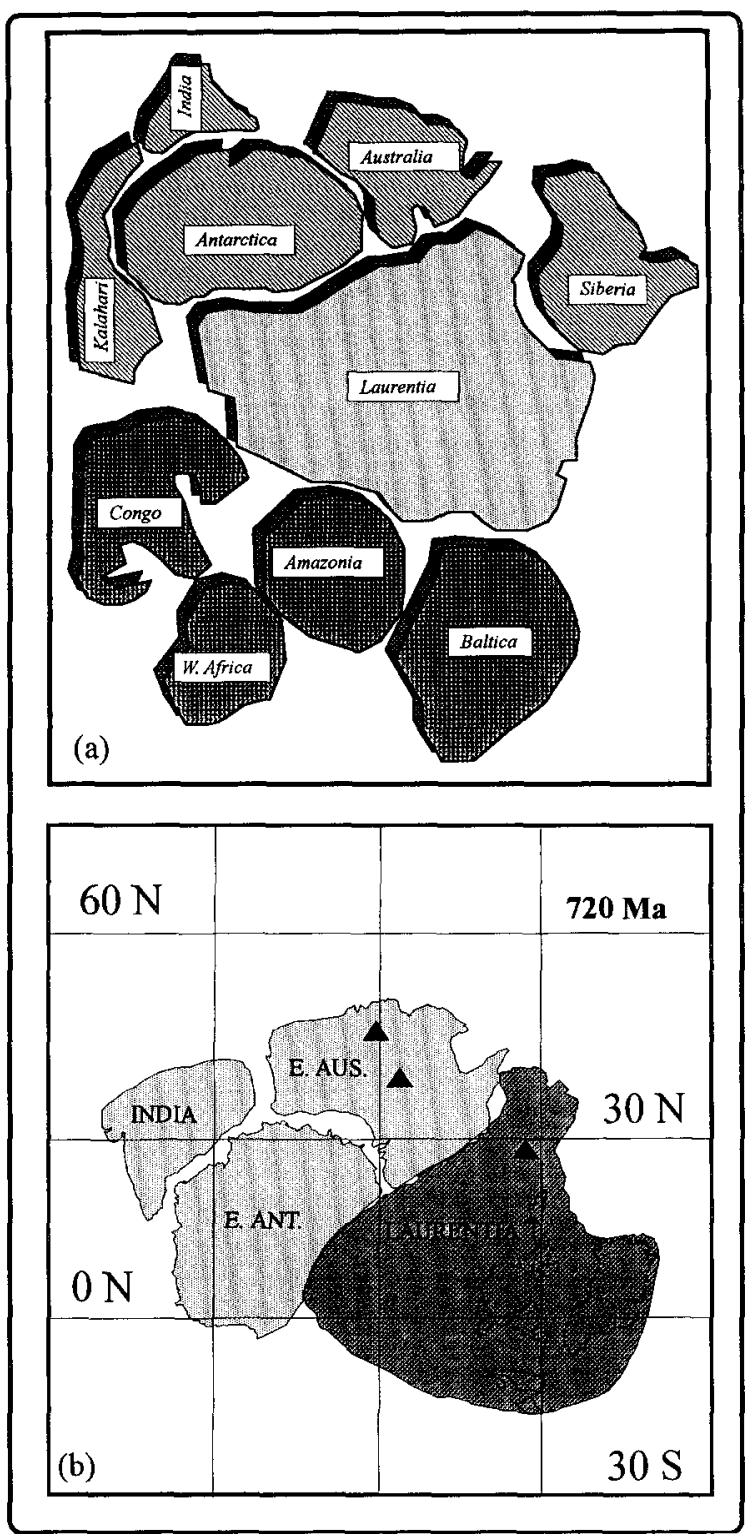

Fig. 4. (a) Late Proterozoic (750 Ma) reconstruction according to [51] and (b) the $720 \mathrm{Ma}$ reconstruction for Laurentia and proto-East Gondwana based on a mean pole from data in [18] at $81^{\circ} \mathrm{S}, 236^{\circ} \mathrm{E}$ (present-day India coordinates). Euler pole rotations: Laurentia $\rightarrow$ India at $56^{\circ} \mathrm{S}, 339^{\circ} \mathrm{E}, \lambda=+166^{\circ}$; East Antarctica $\rightarrow$ India at $4^{\circ} \mathrm{S}, 17^{\circ} \mathrm{E}, \lambda=+92^{\circ}$; East Australia $\rightarrow$ India at $13^{\circ} \mathrm{S}, 13^{\circ} \mathrm{E}, \lambda=+65^{\circ}$. The Sturtian glacial deposits are indicated by $\Delta$ and the extent of the ice sheets is taken to be $\geqslant 25^{\circ}$ latitude according to the model of [14].

have occurred at low latitudes because Laurentia was also thought to have been quasi-static near the equator during the interval 850-505 Ma. Re- cent paleomagnetic data argue strongly against this interpretation and offer the alternative that Laurentia drifted toward the south pole $[15,16]$. Fig. 5 shows the drift history of Laurentia during the interval 625-580 m.y. ago. The Ice Brook glaciations can be argued to have taken place at
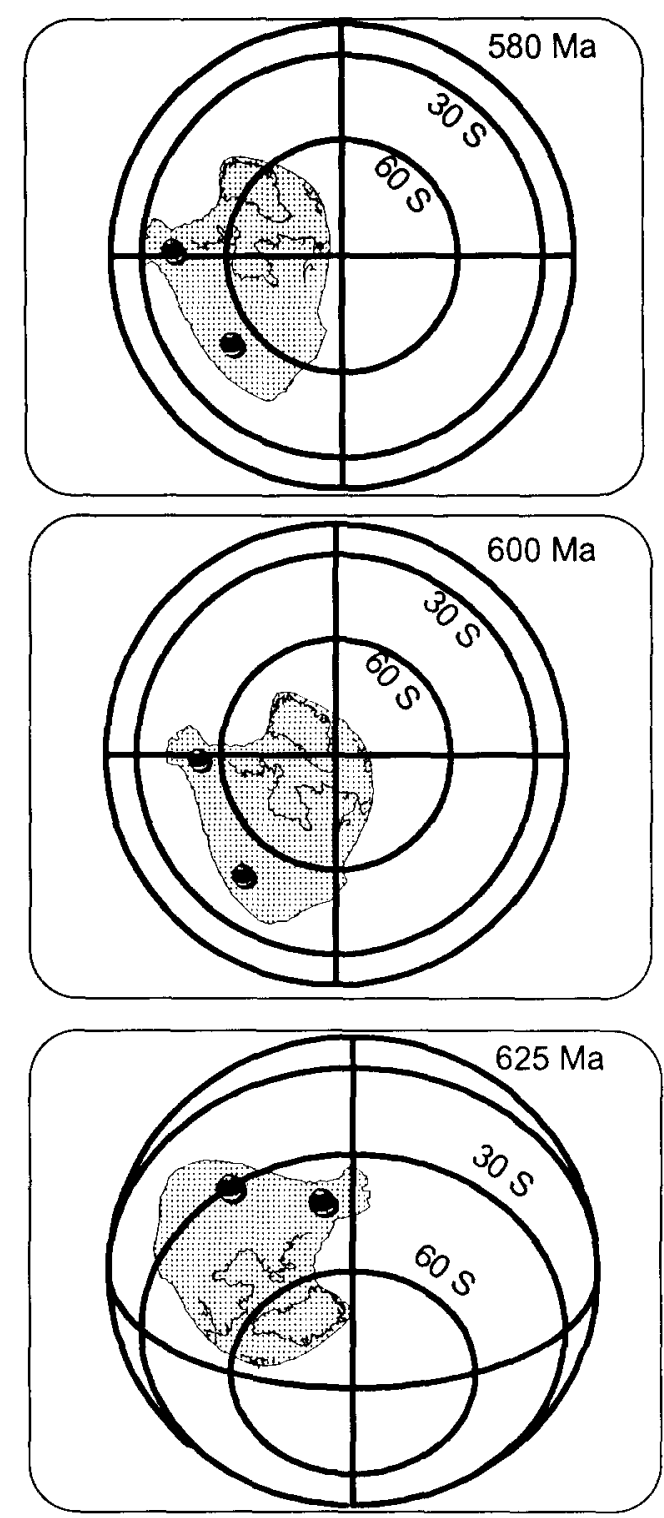

Fig. 5. Drift history of Laurentia for the interval 625-580 Ma along with the location of Ice Brook (Vendian) glacial deposits $(\bullet)$ with ages estimated between 625 and 580 m.y. The occurrence of these glacial deposits is likely to be at $\geqslant 30^{\circ}$ latitude. 
intermediate to high latitudes and may, or may not, have been synchronous with the Marinoan glacial event in Australia.

The Elatina Formation paleomagnetic pole $[1,2]$ has been the cornerstone pole in support of tropical glaciations in the Neoproterozoic and the impetus for proposed orbital changes and 'snowball' earth effects [7,10]. Schmidt et al. [2] noted that the arguments that could be forwarded to refute the validity of the Elatina pole, namely that the inclination was shallowed by compaction or that the varves record a geomagnetic excursion or reversal, are not supported by their interpreta- tion of the paleomagnetic data. The Elatina pole must be regarded as a virtual geomagnetic pole (VGP) because of the short interval of time represented by the varves ( $\approx 60 \mathrm{yrs})$. A VGP indicates that secular variation of the magnetic field has not been averaged by the sampling density and that uncertainty surrounding the calculated paleolatitude for eastern Australia may be larger than the paleomagnetic error; however, it is not certain whether the incomplete averaging of secular variation would lead to an underestimate or overestimate of the paleolatitude. Certainly, the $5^{\circ}$ paleolatitude implied by the Elatina paleomag-

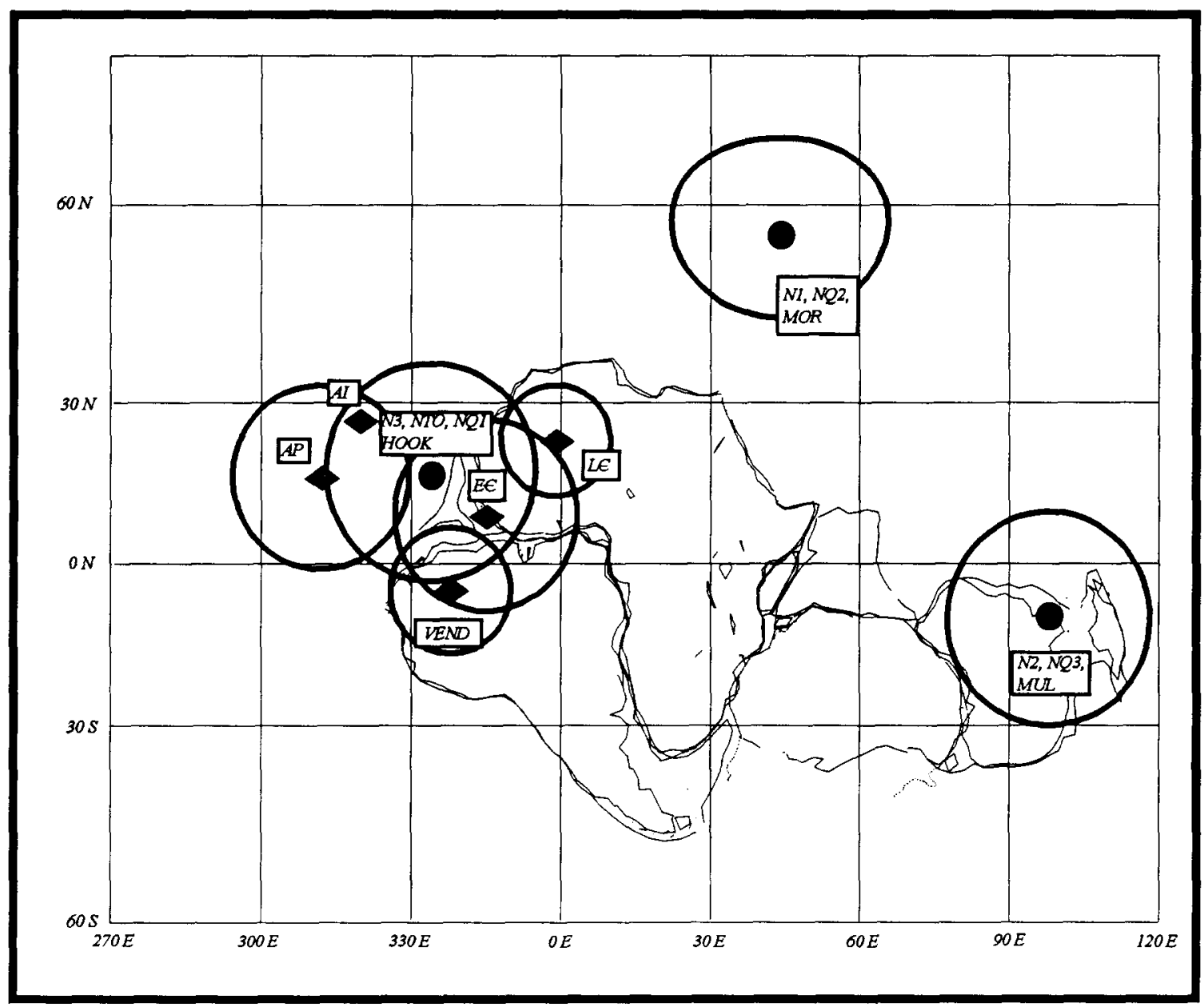

Fig. 6. Paleomagnetic poles from Africa and Australia with their $A_{95}$ circles. The key to the African poles is the same as in Fig. 2. $V E N D=$ Vendian mean pole for Australia; $E C=$ Early Cambrian mean pole for Australia; $L C=$ Late Cambrian mean pole from Australia taken from the compilation in [41] and rotated to African coordinates using the Euler pole at $24.6^{\circ} \mathrm{S}, 297.4^{\circ} \mathrm{E}$, $\lambda=+55.9^{\circ} ; A P=$ Antrim Plateau Volcanics pole; $A I=$ Acraman Impact poles rotated to African coordinates. 
netic data would argue strongly for tropical glaciations, but the critical test for the primary nature of the Elatina pole relies on the validity of the slump (fold) test for the Elatina Formation.

While we cannot dismiss the slump test data outright, we note that the Elatina Formation lies within the Adelaide geosyncline that was deformed during the Delamerian orogen (midCambrian-Ordovician) and that the paleomagnetic pole from the Elatina Formation resembles younger poles from Australia (e.g., see compilation of [41]) and a mean pole for a united Gondwana at $520 \mathrm{Ma}$ (Fig. 6). If the 'slumps' observed in the Elatina Formation are not soft-sediment deformational features, this resemblance of an older pole to younger poles is suggestive of a remagnetization. The argument that a rock shows little evidence of metamorphism due to a tectonic event does not necessarily imply that the rock was not remagnetized during the tectonism. Indeed, sedimentary sequences throughout North Amer- ica that were remagnetized during the late Paleozoic Alleghenian orogeny show little, if any, indication of metamorphism [42]. A remagnetization would invalidate the tropical glaciation implied by the Elatina pole but the effect is that it would leave the paleolatitudinal position of Australia during the Marinoan glaciation unconstrained.

We offer the possibility that parts of Australia and the East Antarctic craton remained linked to Laurentia until a 580-625 Ma rifting event and that the Ice Brook (Laurentia) and Teamsters Creek-Marinoan [43,44] (New South Wales, Australia) glacial intervals occurred just prior to final rifting of Laurentia and Australia. The synchroneity of these glaciations are supported by lithologic and paleontologic correlations between Laurentia and Australia [43,44].

Bond et al. [45] determined that there were two episodes of subsidence along the western margin of Laurentia. Subsidence data from Australia show spatial and temporal patterns that are

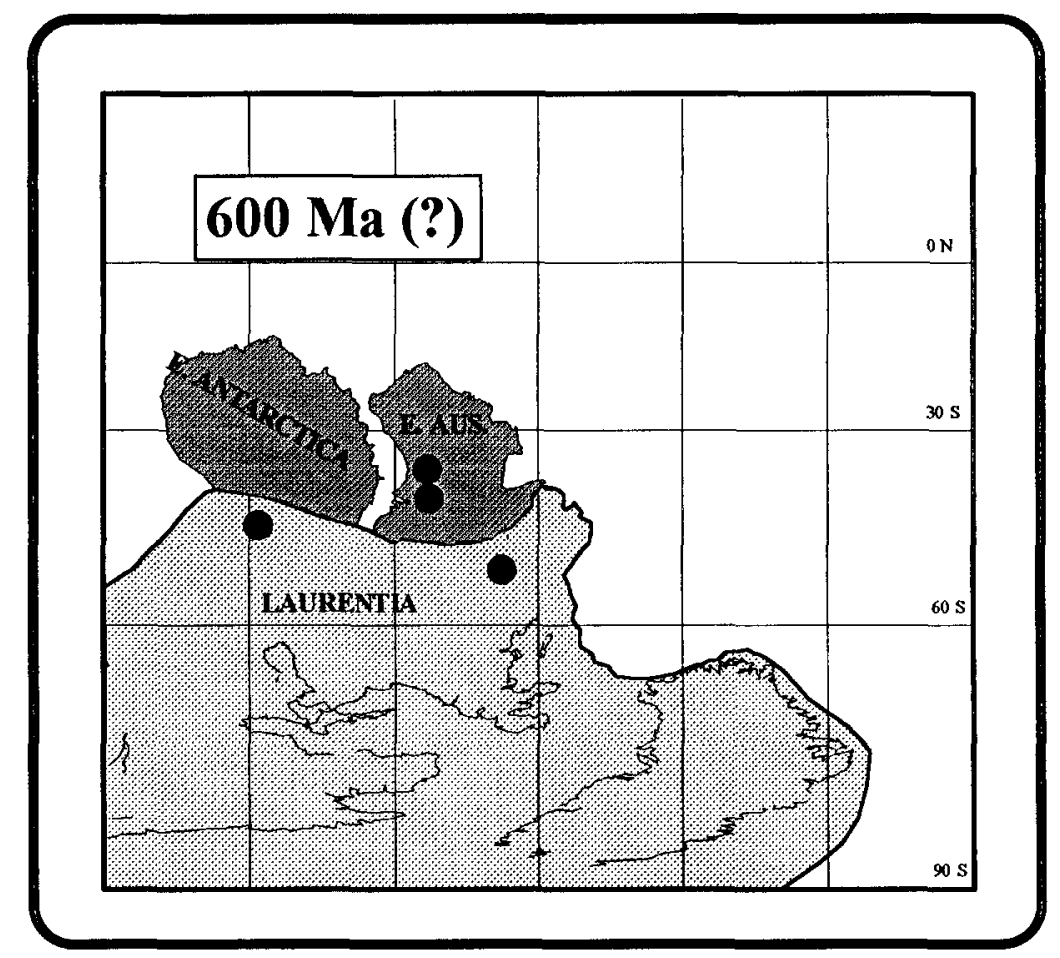

Fig. 7. A possible $600 \mathrm{Ma}$ reconstruction with Australia and East Antarctica attached to western Laurentia. The paleolatitude of Australia is compatible with the Antrim Plateau and Acraman Impact results. The paleolatitude of Laurentia is constrained by the paleomagnetic data reported in [15]. $\bullet$ = Ice Brook-Marinoan glacial deposits including the Elatina Formation. 
similar to those of the western Laurentian margin [46]. In our scenario, the first $720 \mathrm{~m} . \mathrm{y}$. old thermal event is related to the outboard rifting of parts of East Gondwana (India, western Australia, Madagascar(?), Sri Lanka(?), Enderby Land, Lützow-Holm, Kalahari(?)) from western Laurentia or the rifting of Baltica and Siberia from northwestern Laurentia. This rifting is expressed minimally in the thermal subsidence curves of western Laurentia and eastern Australia. Additionally, both lack a well-developed passive margin sequence [45].

The renewed subsidence and passive margin development in western Laurentia during the interval 550-625 Ma was previously attributed to (a) reactivation of subsidence coincident with the main rifting event along eastern Laurentia [18] or (b) the rifting of piece ' $\mathrm{X}$ ' from western Laurentia [47]. In our scenario, this subsidence and passive margin development is due to the rifting of eastern Australia and parts of the East Antarctic craton from western Laurentia. There is some paleomagnetic support for this scenario. The paleomagnetic poles from the Acraman impact structure and Antrim Plateau volcanics support the intermediate latitudes for Australia at 600 Ma; however, they too fall near the mean $520 \mathrm{Ma}$ pole for Gondwana [41]. If these poles provide a reasonable estimate for the paleolatitude of Australia at $600 \mathrm{Ma}$ the reconstruction shown in Fig. 7 offers an explanation for the synchroneity of glaciation and passive margin development on Laurentia and Australia without the need for a 'snowball' earth.

\subsection{Baltica and other continents}

The paleolatitudinal position of Baltica during the Vendian-Varangian glaciations (580-625 Ma) is entirely located above $40^{\circ}$ latitude $[19,48]$. Fig. 8 shows the paleogeographic reconstruction for Baltica during this time interval. The Vendian glaciations on Baltica are polar to subpolar and in direct conflict with the high obliquity model of Williams [7]. Estimates for the paleolatitudinal positions of the Armorican and Avalonian terranes during the latest Precambrian-early Cambrian indicate that both of these blocks were

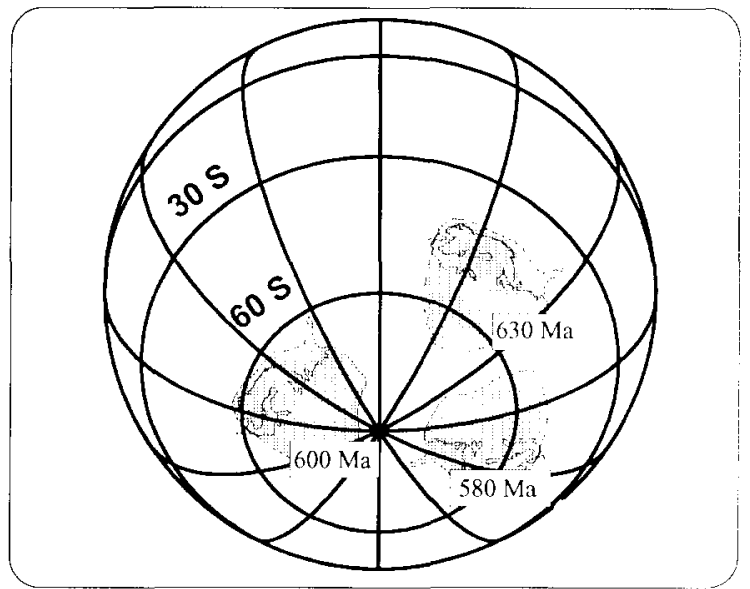

Fig. 8. Paleopositions of Baltica at 630,600 and 580 Ma based on paleomagnetic data compilations $[19,48]$. The Vendian glaciations are restricted to polar and subpolar regions, in direct conflict with the high-obliquity earth model of Williams [7].

located above $30^{\circ}$ latitude [49]. Avalonian glacial deposits of Vendian age are now located on the North American continent (Fig. 1), but only after their Ordovician-Silurian accretion. Results from the former Soviet Union's database cannot be fully evaluated due to difficulty in obtaining and translating the original results. The available data from the compiled Soviet database show a range of equatorial to polar latitudes for different glacial rocks of the Neoproterozoic [50]. There is a paucity of reliable paleomagnetic data from other continents (Antarctica, India and South America) for the Neoproterozoic interval and therefore arguments regarding the paleolatitudinal position of these blocks must await further refinement of their respective APWPs.

\section{Conclusions}

We conclude that it is very likely that all the Neoproterozoic glacial sequences were deposited at latitudes $\geqslant 25^{\circ}$ from the equator (Table 1 ). This observation places these glaciations at latitudes above the present-day tropics and within latitudes that could be glaciated by calling on a $5-10 \%$ decrease in solar luminosity, lower $\mathrm{CO}_{2}$ and coupling to Milankovitch orbital variations 
[14]. Such an interpretation also supports the conformable sequences of warm climate and cold-climate sediments through a simple waxing and waning of glacial climate, coupled in some cases with drift of continents toward the equator. A drastic change in the earth's obliquity cannot account for the distribution of these strata because the climatologic effects of such a change are restricted to zones near the equator.

The paleomagnetic data from the Elatina Formation (Australia) remain somewhat enigmatic because they indicate that the glacial varves accumulated at low latitudes. We offer an alternative reconstruction at $600 \mathrm{Ma}$ that maintains the link of eastern Australia with western Laurentia. If our reconstruction is valid, the Marinoan glaciations occurred at latitudes above $30^{\circ}$. We also note here that if the Elatina data are valid they do not necessarily imply either global glaciation or a non-uniformitarian Neoproterozoic climate. Eyles [9] relates the Marinoan and other Neopro- terozoic glacial deposits to the elevated regions of active tectonic settings and claims that although these glaciations may be low latitude, they may not be low elevation.

Our preferred interpretation of the paleomagnetic data is that the Neoproterozoic glacial/ interglacial intervals are likely non-synchronous and occurred as continents drifted into, or out of, latitudes $\geqslant 25^{\circ}$. Therefore, the Neoproterozoic glaciations are somewhat anomalous because they extended into latitudes lower than those of the Paleozoic and Cenozoic glaciations but can be fitted to simple climate models using a juvenile Sun of lower luminosity.

\section{Acknowledgements}

We wish to thank T.J. Crowley and Michelle Hall for the inspiration to pursue this research and review of early drafts of the manuscript. We

Table 1

Estimated paleolatitudes for late Proterozoic glaciogenic deposits

\begin{tabular}{|c|c|c|}
\hline Continent or Block & Glacial Epoch ${ }^{I}$ & Paleolatitude Estimate $^{2}$ \\
\hline \multicolumn{3}{|l|}{ Africa } \\
\hline Congo Craton & Sturtian & ?? likely alpine glacial deposits \\
\hline South Africa-Namibia & Sturtian & $\approx 56^{\circ}(?)$ \\
\hline South Africa-Namibia & Marinoan-Vendian & $\approx 12^{\circ} \pm 20^{\circ}$ \\
\hline West Africa & Marinoan-Vendian & $\geq 45^{\circ}$ \\
\hline \multicolumn{3}{|l|}{ China } \\
\hline South China Block & Sinian & $40^{\circ} \pm 7^{\circ}$ \\
\hline North China Block (a) & Sinian & $23^{\circ}+12^{\circ}$ \\
\hline North China Block (b) & Sinian & $\geq 42^{\circ}$ \\
\hline \multicolumn{3}{|l|}{ Laurentia } \\
\hline North America & Rapitan-Sturtian & $27^{\circ}$ \\
\hline North America & Ice Brook-Vendian & $\geq 45^{\circ}$ \\
\hline \multicolumn{3}{|l|}{ Australia } \\
\hline E. Australia & Sturtian & $\geq 32^{\circ}$ \\
\hline Australia & Marinoan & $? ?\left(\geq 30^{\circ}\right)$ \\
\hline \multicolumn{3}{|l|}{ Baltica } \\
\hline Baltica & Vendian & $\geq 40^{\circ}$ \\
\hline \multicolumn{3}{|l|}{ Avalon } \\
\hline Avalon & Vendian & $\approx 60^{\circ}$ \\
\hline \multicolumn{3}{|l|}{ Armorica } \\
\hline Armorica & Vendian & $\geq 30^{\circ}$ \\
\hline
\end{tabular}

${ }^{1}$ The glacial epochs are defined as Sturtian $(\approx 750-700 \mathrm{Ma})$, Marinoan-Vendian-Ice Brook $(\approx 625-580$ Ma) and Sinian $(\approx 600-550 \mathrm{Ma}) .{ }^{2}$ See text for complete details of these paleomagnetically constrained paleolatitudes. 
also thank John Stamatakos, Ben van der Pluijm, Brad Opdyke and Jim Walker for valuable comments on early drafts. Editorial reviews by Lisa Tauxe and an anonymous reviewer greatly improved the manuscript, as did a critical review by Joe Kirschvink. This research was supported by the Scott Turner Fund of the University of Michigan, the Geological Society of America, Sigma Xi and by the Division of Earth Sciences, National Science Foundation, grant EAR 92-05815.

\section{References}

[1] B.J.J. Embleton and G.E. Williams, Low paleolatitude of deposition for late Precambrian periglacial varvites in South Australia: implications for paleoclimatology, Earth Planet. Sci. Lett. 79, 419-430, 1986.

[2] P.W. Schmidt, G.E. Williams and B.J.J. Embleton, Low paleolatitude of Late Proterozoic glaciation: Early timing of remanence in haematite of the Elatina Formation, South Australia, Earth Planet. Sci. Lett. 105, 355-367, 1991.

[3] A. Kröner, M.O. McWilliams, G.J.B. Germs, K.L. Schalk and A. Reid, Paleomagnetism of late Precambrian to early Paleozoic mixtite-bearing formations in Namibia (southwest Africa): The Nama Group and Blaubeker Formation, Am. J. Sci. 280, 942-968, 1980.

[4] H. Zhang and W. Zhang, Paleomagnetic data, late Precambrian magnetostratigraphy and tectonic evolution of eastern China, Precambrian Res. 29, 65-75, 1985.

[5] Li Yianping, Li Yongan, R. Sharps, M. McWilliams and Z. Gao, Sinian paleomagnetic results from the Tarim block, western China, Precambrian Res. 49, 61-71, 1991.

[6] H.C. Palmer, W.R.A. Barager, M. Fortier and J.H. Foster, Paleomagnetism of Late Proterozoic rocks, Victoria Island, Northwest Territories, Canada, Can. J. Earth Sci. 20, 1456-1469, 1983.

[7] G.E. Williams, History of the Earth's obliquity, Earth-Sci. Rev. 34, 1-45, 1993.

[8] V.R. Oberbeck, J.R. Marshall and H. Aggarwal, Impacts, tillites, and the breakup of Gondwanaland, J. Geol. 1-15, 1992.

[9] N. Eyles, Earth's glacial record and its tectonic setting, Earth-Sci. Rev. 35, 1-248, 1993.

[10] J.L. Kirschvink, Late Proterozoic low-latitude global glaciation: The snowball Earth, in: The Proterozoic Biosphere: A Multidisciplinary Study, J.W. Schopf and C. Klein, eds., pp. 51-52, Cambridge University Press, Cambridge, 1992.

[11] R.P. Sheldon, Ice-ring origin of the Earth's atmosphere and hydrosphere and Late Proterozoic-Cambrian phosphogenesis, Geol. Surv. India Spec. Publ. 17, 321-362, 1984.
[12] J.C. Crowell, Ice ages recorded on Gondwanan continents, Trans. Geol. Soc. S. Afr. 86, 238-261, 1983.

[13] H.G. Marshall, J.C.G. Walker and W.R. Kuhn, Long term climate change and the geochemical cycle of carbon, J. Geophys. Res. 93, 791-801, 1988.

[14] T.J. Crowley and S.K. Baum, Effect of decreased solar luminosity on Late Precambrian ice extent, J. Geophys. Res. 98, 16723-16732, 1993.

[15] J.G. Meert, R. Van der Voo and T. Payne, Paleomagnetic investigation of the Catoctin volcanic province: $A$ new Vendian-Cambrian apparent polar wander path for North America, J. Geophys. Res., in press, 1994.

[16] D.T.A. Symons and D. Chiasson, Paleomagnetism of the Callander Complex and the Cambrian apparent polar wander path for North America, Can. J. Earth Sci. 28, 355-363, 1991.

[17] Z. Wang, Paleomagnetism of South China and its tectonic and geologic implications, Dissert., Univ. Michigan, 1993.

[18] C.McA. Powell, M.W. McElhinny, Z.X. Li, J.G. Meert and J.K. Park, Paleomagnetic constraints on timing of the Neoproterozoic breakup of Rodinia and Cambrian formation of Gondwana, Geology 21, 889-892, 1993.

[19] T.H. Torsvik, D. Roberts and A. Siedlecka, Riphean and Vendian paleomagnetic data from northeast Russia and northern Norway: Review and supplementary data, Nor. Geol. Tidsskr., Spec. Ed., in press, 1994.

[20] W.S.B. Paterson, Laurentide ice sheet, estimated volumes during late Wisconsin, Rev. Geophys. Space Phys. 10, 885, 1972.

[21] W.R. Peltier, Models of glacial isostasy and relative sealevel, in: Dynamics of Plate Interiors, Bally et al., eds., Am. Geophys Union Geodyn. Ser., pp. 111-128, 1980.

[22] L.A. Frakes, Climates throughout Geologic Time, Elsevier, Amsterdam, 1979.

[23] W.R. Ward, Comments on the long-term stability of the Earth's obliquity, Icarus 50, 444-448, 1982.

[24] N.M. Chumakov and D.P. Elston, The paradox of Late Proterozoic glaciations at low latitudes, Episodes 12, 115-120, 1989.

[25] J.P. Vanyo and S.M. Awramik, Stromatolites and EarthSun-Moon dynamics, Precambrian Res. 29, 121-142, 1985.

[26] A. Kröner, Non-synchroneity of late Precambrian glaciations in Africa, J. Geol. 85, 289-300, 1977.

[27] A.W. Brinkman and J. McGregor, The effect of the ring system on the solar radiation reaching the top of Saturn's atmosphere: direct radiation, Icarus 38, 479-482, 1981.

[28] W.B. Harland, The Proterozoic glacial record, in: Proterozoic Geology, L.G. Medaris, C.W. Byers, D.M. Mickleson and W.C. Shanks, eds., Geol. Soc. Am. Mem. 161, 279-288, 1983.

[29] G. Vidal and A.H. Knoll, Radiations and extinctions of plankton in the late Proterozoic and Early Cambrian, Nature 297, 57-60, 1983.

[30] L.J.G. Schermerhorn, Late Proterozoic glaciation in light of $\mathrm{CO}_{2}$ depletion in the atmosphere, in: Proterozoic 
Geology, L.G. Medaris, C.W. Byers, D.M. Mickleson and W.C. Shanks, eds., Geol. Soc. Am. Mem. 161, 309-315, 1983.

[31] J.D.A. Piper, Paleomagnetism and the Continental Crust, Wiley, New York, 1987

[32] L. Cahen, N.J. Snelling, J. Delhal and J.R. Vail, The Geochronology of Equatorial Africa, North Holland, Amsterdam, 1984.

[33] L. Cahen and J. Lepersonne, Proterozoic diamictites of Lower Zaire, in: Earth's pre-Pleistocene Glacial Record, M.J. Hambrey and W.B. Harland, pp. 153-157, Cambridge University Press, London, 1981.

[34] J.D.A. Piper, A paleomagnetic study of the Bukoban System, Tanzania, Geophys. J.R. Astron. Soc. 28, $111-$ 127, 1972.

[35] M.J. Hambrey and W.B. Harland, eds., Earth's prePleistocene Glacial Record, Cambridge University Press, London, 1981.

[36] M.O. McWilliams and A. Kröner, Paleomagnetism and tectonic evolution of the Pan-African Damara Belt, southern Africa, J. Geophys. Res. 86, 5147-5162, 1981.

[37] R. Van der Voo and J.G. Meert, Late Proterozoic paleomagnetism and tectonic models: A critical appraisal, Precambrian Res. 53, 149-163, 1991.

[38] D.L. Reid, I.G.D. Ransome, T.C. Onstott and C.J. Adams, Time of emplacement and metamorphism of late Precambrian mafic dykes associated with the Pan-African Gariep orogeny, southern Africa: Implications for the age of the Nama Group, J. Afr. Earth Sci. 13, 531-541, 1991.

[39] X.X. Zhao, R.S. Coe, C. Liu and Y. Zhou, New Cambrian and Ordovician paleomagnetic poles for the North China block and their paleogeographic implications, J. Geophys. Res. 97, 1768-1788, 1992.

[40] I.W.D. Dalziel, Pacific margins of Laurentia and East Antarctica-Australia as a conjugate rift pair: Evidence and implications for an Eocambrian supercontinent, Geology 19, 598-601, 1991.

[41] Z.X. Li and C.McA. Powell, Late Proterozoic to Early Paleozoic paleomagnetism and the formation of Gondwanaland, in: Gondwana 8: Assembly, Evolution and
Dispersal, R.H. Findlay et al., eds., pp. 9-21, Balkema, Rotterdam, 1993.

[42] C. McCabe and R.D. Elmore, The occurrence and origin of Late Paleozoic remagnetization in the sedimentary rocks of North America, Rev. Geophys. 27, 471-494, 1989

[43] G.M. Young, Neoproterozoic glaciation in the Broken Hill area, New South Wales, Australia, Bull. Geol. Soc. Am. 104, 840-850, 1992.

[44] J.D. Aitken, Two late Proterozoic glaciations, Mackenzie mountains, northwestern Canada, Geology 19, 445-448, 1991.

[45] G.C. Bond, P.A. Nickeson and M.A. Kominz, Breakup of a supercontinent between $625 \mathrm{Ma}$ and $555 \mathrm{Ma}$ : New evidence and implications for continental histories, Earth Planet. Sci. Lett. 70, 325-345, 1984

[46] J.F. Lindsay, R.J. Korsch and J.R. Wilford, Timing the breakup of a Proterozoic supercontinent: Evidence from Australian intracratonic basins, Geology 15, 1061-1064, 1987.

[47] P.K. Link, N. Christie-Blick, W.J. Devlin, D.P. Elston, R.J. Horodyski, M. Levy, J.M.G. Miller, R.C. Pearson, A. Prave, J.H. Stewart, D. Winston, L.A. Wright and C.T. Wrucke, Middle and Late Proterozoic stratified rocks of the western U.S. Cordillera, Colorado Plateau and Basin and Range, in: The Geology of North America, Vol. C-2, Precambrian, Conterminous U.S., J.C. Reed et al., eds., pp. 463-495, Geol. Soc. Am., Boulder, Colo., 1992.

[48] T.H. Torsvik, M.A. Smethurst, R. Van der Voo, A. Trench, N. Abrahamsen and E. Halvorsen, Baltica. A synopsis of Vendian-Permian paleomagnetic data and their paleotectonic implications, Earth-Sci. Rev. 3, 133$152,1992$.

[49] R. Van der Voo, Paleomagnetism of the Atlantic, Tethys and Iapetus Oceans, Cambridge University Press, Cambridge, 1993 .

[50] A.N. Khramov, Paleomagnetology, Nedra, Leningrad, 1982 (in Russian).

[51] P.F. Hoffman, Did the breakout of Laurentia turn Gondwanaland inside-out?, Science 252, 1409-1412, 1991. 